Мирко Обрадовић

Универзитет у Београду

Филозофски факултет

Одељење за историју

mdobrado@f.bg.ac.rs
Оригинални научни рад

примљено: 30. мај 2011

прихваћено: 1. октобар 2011

\title{
МУДРАЦ БИЈАНТ ИЗ ПРИЈЕНЕ: ТРАДИЦИЈА О ВРЕМЕНУ У КОЈЕМ ЈЕ ЖИВЕО, ЊЕГОВОМ ПОРЕКЛУ И ЗНАЧЕЊУ ЊЕГОВОГ ИМЕНА
}

Сажетак: У раду се истражује традиција о Бијанту из Пријене, једном од седморице грчких мудраца архајске епохе, његовом пореклу и времену у коме је живео, као и о његовом личном имену. Доказује се да је време Бијантове животне зрелости највероватније средина VI века пре наше ере, а не крај VII или почетак VI века како се то обично претпоставља у науци. Такође се у другом делу рада расправља о могућим значењима Бијантовог имена, које је готово сигурно преузето из херојског репертоара грчких имена са намером да се његова породица, која је очигледно припадала аристократији Пријене, и на овај начин повеже са светом хероја, а преко њих и са светом богова.

Кључне речи: Бијант, седморица мудраца, грчка антропонимија, архајска епоха, мит, традиција, историја, политика, културне вредности.

Сачувана традиција о Бијанту из Пријене је углавном доста позна, исто као и у случају већине других славних Грка који су уврштени у списак седморице мудраца архајске епохе ( $\tau \widetilde{\omega} v \dot{\varepsilon} \pi \tau \dot{\alpha}$ боф $\widetilde{\omega})$. У овај списак су, поред Бијанта, чије се име налази на свим до данас познатим листама, најчешће улазили и Талес из Милета, Солон из Атине, Питак из Митилене, Перијандар из Коринта, Хилон из Спарте и Клеобул из Линда, али понегде и многе друге истакнуте историјске или полулегендарне личности из архајске епохе, попут Епименида Крићанина, Анахарсида Скита или Мисона из Хена. ${ }^{1}$ Како то обично бива са великим људима који су обележили одређену епоху, о њима су се након њихове смрти шириле различите легенде, тако да није увек једноставно одвојити оно поуздано и историјско од митског и легендарног. Али за разлику од, на пример, Перијандра из Коринта, Солона Атињанина, Питака из Митилене или Хилона Лакедемоњанина који су били владари или бар привремено управљали својим полисима и остали

\footnotetext{
${ }^{1}$ Тако, на пример, Платон очекивано изоставља Перијандра са листе, јер је овај био тиранин у Коринту, а тирани не могу бити филозофи и мудраци, и на његово место ставља Мисона из Хена. Упор. Pl. Prt. 343 .
} 
упамћени као велики државници, Бијант није остварио тако успешну политичку каријеру. Бавио се адвокатуром и у тој професији је сматран у своје време готово ненадмашним, ${ }^{2}$ али је такође у важним догађајима за свој родни град и за целу Јонију покушавао да личним ауторитетом усмери политичка збивања у одређеном правцу и у општем интересу. Управо ти, често узгредни подаци о Бијантовој политичкој активности омогућују да се прецизније одреди време у којем је овај мудрац живео и стварао.

Највише података о Бијантовом животу и раду дају, као и у случају осталих раних мудраца, Животи и мишљења истакнутих филозофа Диогена Лаертија. ${ }^{3}$ Иако је реч о временски доста позном саставу (насталом највероватније у 3. веку н.е.), ово дело је и данас важан извор за изучавање античке мисли, јер бележи цитате из бројних у потпуности изгубљених извора. Ако се, међутим, има у виду и свеукупност сачуване традиције, изворни материјал који се односи на ове ране филозофе састоји се такође у највећој мери од њихових мудрих изрека или је управо анегдотски по свом карактеру. Нама данас преостаје да само претпостављамо да локалне приповести и легенде, анегдоте и кратке и језгровите изреке могу одражавати и стварне историјске догађаје. На основу таквих казивања и података из друге и треће руке у стању смо ипак да, са мањом или већом вероватноћом, сместимо поменуте мудраце и ране филозофе у сасвим одређени временски и историјски оквир. Треба притом имати у виду да је још античка традиција настојала да све ове људе доведе непосредно у везу и представи их као савременике који су се, иако су својим пореклом и животним судбинама били раштркани у различитим полисима широм хеленског света, не само међусобно познавали, већ и дружили и често размењивали мишљења о различитим питањима. Синхронизми овога типа на којима инсистирају антички писци, који су заправо анахронизми и не пружају основу за прецизно датовање, забележени су, на пример, код Плутарха у Биографији Солона у легенди о златном троношцу који је кружио између мудраца док није завршио као заветни дар Аполону у Теби, ${ }^{4}$ или у његовом трактату насловљеном Гозба седморице мудраца (Septem sapientium convivium), где је управо реч о сусрету на гозби у Коринту готово свих горе наведених мудраца коју је уприличио тиранин и мудрац Перијандар. ${ }^{5}$ Слични су по изворној вредности и састави псеудоепистолографског карактера који имају да сведоче о међусобној комуникацији и тобожњем дописивању између мудраца. ${ }^{6}$

\footnotetext{
${ }^{2} \mathrm{C}$ тим у вези, у традицији је остала забележена и изрека ,јачи у парничењу од Бијанта из Пријене“, која је приписивана славном песнику Хипонакту из Ефеса и односила се на некога ко се посебно истицао у адвокатури и бескомпромисној одбрани интереса клијената на суду. Упор. Strab. XIV 1, 12; Diog. Laert. I 84.

${ }^{3}$ Diog. Laert. I 82-88. Текст Диогена Лаертија је наведен у раду према нумерацији у Лонговом оксфордском издању: Diogenis Laertii vitae philosophorum, Vol. 1 (ed. H. S. Long), Oxford 1964.

${ }^{4}$ Plut. Sol. 4.

${ }^{5}$ Plut. Sept. sap. conv. 146-164.

${ }^{6}$ Упор. нпр. Diog. Laert. I 44, писмо Талеса упућено Солону у коме се помиње и преписка са Бијантом који позива остале мудраце да се преселе код њега и да сви заједно наставе да живе у Пријени. Уопште о псеудоисторијској кореспонденцији код Хелена, вид. С. D. N. Costa, Greek Fictional Letters: a Selection
} 
Остављајући по страни све ове анахронизме, када се ради конкретно о Бијанту из Пријене и о времену његове зрелости и активности, она се, следећи традицију, датује у распону од чак више од стотину година: 1) у време Другог месенског рата (средина 7. века пре н.е.), односно 2) више од пола века касније у периоду владавине лидијског краља Алијата (владао између отприлике 610. и 560. године пре н.е.), или опет 3) у време владавине последњег лидијског краља Креза и у годинама персијског освајања западних делова Мале Азије (између отприлике 560. и 540. године пре н.е.). Уз чак и претпостављени дуг животни век мудраца, ${ }^{7}$ тешко је и помислити да је Бијант могао бити активан у временском периоду од стотинак година, између отприлике средине VII и средине VI века. Има зато модерних научника који усвајају као средње решење прве деценије владавине краља Алијата (период између 610. и 580. године пре н.е.) као време вероватне Бијантове зрелости а што би било у складу и са раширеном античком традицијом која Бијанта чини савремеником Солона, Талеса, Перијандра и Питака. ${ }^{8}$ Ова тврдња је, међутим, бар када је реч о Бијанту, ако занемаримо наведене анахронизме, заснована готово искључиво на једној анегдоти која бележи Бијантово лукавство уз помоћ којег је успео да одбрани свој родни град Пријену од напада лидијског краља Алијата. Да би, наиме, одвратио Алијата од опсаде Пријене, прича каже да је мудри Пријењанин угојио две мазге и послао их намерно у Алијатов табор. Рачунао је да ће непријатељ одустати од опсаде процењујући да је град Пријена добро снабдевен залихама и да може да издржи дугу опсаду када су и мазге Пријењана тако добро ухрањене. Лукавство је дало резултат и у коначном исходу је Алијат закључио са Пријеном мир. ${ }^{9}$ Ако, међутим, у овој причи има уопште историјске истине, она онда и није нужно морала потицати из првих деценија Алијатове владавине (између 610. и 580. године), већ се такође могла односити на неку од година близу краја његовог краљевања (око 560. године пре н.е.).

С друге стране, одређени историјски подаци упућују најпре да је најпознатији Пријењанин у историји нешто млађи од већине осталих мудраца, попут Перијандра, Питака или Солона, чију зрелост и политичку активност можемо са великом сигурношћу датовати у крај VII и почетак VI века, док би он сам пре могао бити савременик Алијатовог наследника и последњег лидијског краља Креза (владао отприлике између 560. и 546. године пре н.е.). Ови изворни подаци, иако такође анегдотски по свом карактеру, имају нешто већу вредност, јер их бележи Херодот који је, по времену у коме је живео, од све преостале сачуване наративне традиције ипак најближи Бијантовом добу. Херодот доводи у везу Бијанта и Креза када

with Introduction, Translation and Commentary, Oxford 2001; P. A. Rosenmeyer, Ancient Greek Literary Letters: Selections in Translations, New York 2006, 97-129.

7 Забележено је у традицији да је Бијант доживео дубоку старост и да је умро бранећи свог клијента на суду. Упор. Diog. Laert. I 84.

${ }^{8}$ За мишљење да се за све горе наведене мудраце, укључујући ту и Бијанта, време зрелости и политичке активности може најпрецизније датовати у крај VII, односно почетак VI века пре н.е., упор. нпр. R. W. Wallace, Charismatic Leaders, A Companion to Archaic Greece (eds. K. A. Raaflaub and H. van Wees), Blackwell Publishing, Oxford 2009, 421.

${ }^{9}$ Diog. Laert. I 83. 
приповеда о савету који је Бијант из Пријене, или можда опет Питак из Митилене, дао лидијском краљу у вези са краљевом намером да изгради флоту са којом би овладао грчким острвима. ${ }^{10}$ Мудрац (Бијант или Питак) је, наводно, успео да одврати краља од ове намере, а ако и ову причу прихватимо такође за познију фабрикацију и типичан дидактички дијалог између мудраца и тиранина (попут оног далеко познатијег између Солона и Креза), онда свакако друга Херодотова прича која се тиче како Бијанта тако и положаја грчких градова у време персијског освајања Јоније, није изгледа сасвим лишена веродостојности. Бијант је, наводи Херодот, након персијског освајања Мале Азије, саветовао Јонцима да се колективно иселе на запад на острво Сардинију да би избегли конфронтацију са Персијанцима и готово неизбежан пораз. ${ }^{11}$ Херодот изричито наводи да су се Јонци састали у свом заједничком светилишту Панјониону да расправе шта им је чинити, а да је Бијантов предлог, који се и самом Херодоту учинио најбољим, предвиђао остваривање националног јединства образовањем новог заједничког полиса за све јонске градове (уместо дотадашњих 12) на далеком острву где би били безбедни а могли би и сами да наметну своју власт другима. Острво Сардинију су Грци онога времена сматрали највећим од свих острва, а Бијантов савет је могао бити у складу са раширеним веровањем међу јонским Грцима о постојању обећане земље на Западу где би Хелени могли да остваре неспутано све своје потенцијале. ${ }^{12}$ Из тог разлога ову причу не треба тек тако одбацити и она би више него иједна претходна могла да нам пружи веродостојне податке о времену када је мудрац из Пријене био на свом врхунцу. Одатле би се и дало закључити да је Бијант могао бити рођен најпре крајем VII или почетком VI века, а да доба његове зрелости у том случају пада у деценије око средине VI века. У то време био је стар између 50 и 60 година, а то су у антици, када је просечан животни век био далеко краћи, биле озбиљне године због којих је Бијант и могао бити сматран већ довољно искусним и цењеним да наступа у име свог града и даје савете осталим Јонцима.

Да је време Бијантове животне зрелости најбоље датовати у отприлике средину VI века пре н.е. показује, како се чини, и занимљиво епиграфско сведочанство са острва Сама из хеленистичког периода. ${ }^{13}$ Иако се догађаји у којима се помиње Бијант не могу на основу текста натписа прецизно датовати, сигурно је да потичу из VI века пре н.е. и такође потврђују огромни ауторитет који је Пријењанин у то доба уживао код својих савременика. Документ о коме је реч тиче

\footnotetext{
${ }^{10}$ Hdt. I 27. Иако Херодот наводи да је саветник могао бити како Бијант тако и Питак, извесно је да је Питак из Митилене био знатно старији од Бијанта и Креза и да је припадао претходној генерацији, пошто je умро већ око 570. године, дакле читаву деценију пре почетка Крезове владавине. Упор. D. Asheri, A Commentary on Herodotus Books I-IV, Oxford 2007, 96.

${ }^{11}$ Hdt. I 170.

${ }^{12}$ Упор. P. Ceccarelli, De la Sardaigne à Naxos: le rôle des îles dans les Histoires d'Hérodote, Impressions d'îles (ed. F. Létoublon), Toulouse 1996, 41-55; N. Cusumano, Biante e la Sardegna: libertà e felicità in Erodoto, Kokalos Suppl. 15. Erodoto e l'occidente, Palermo 1999, 139-196. Вид. такође N. Demand, Herodotus and Metoikesis in the Persian Wars, AJPhil 109, Baltimore 1988, 416-423.

${ }^{13}$ Welles, RC 7, редови 21-5 (C. B. Welles, Royal Correspondence in the Hellenistic Period, New Haven 1934)

= I. Priene 500 (F. Hiller von Gaertringen, Inschriften von Priene, Berlin 1906).
} 
се вековног спора око територија између два јонска града - Бијантове Пријене и Самљана који су од давнина полагали право на део земље на малоазијском копну наспрам њиховог острва (Сама). Два јонска града су се дуго спорила, чак и међусобно ратовала око спорне територије, а често су, у немогућности да сами реше проблем, износили предмет пред међународну арбитражу. Тако су се као арбитри у спору јављали и хеленистички краљеви, острво Родос, на гласу као међународни арбитар од великог угледа у хеленистичком периоду, а на крају и Римљани. ${ }^{14}$ у наведеном документу који представља краљевско писмо (Welles, $R C$ 7) арбитар је краљ Лисимах, један од наследника Александра Великог (крај IV - почетак III века пре н.е.), а изричито се наводи да је управо Бијант из Пријене успео да за дужи временски период оконча непријатељства и да у име Пријењана начини споразум са Самљанима. Најбоље је зато и ове догађаје у којима је истакнуту улогу имао мудрац из Пријене датовати у средину VI века, односно у деценије између 560. и 540. године пре н.е.

Поред свих ових занимљивих података из наративних и документарних извора, о самом Бијанту из Пријене доста тога се може рећи и на основу његовог личног имена, као и на основу патронимика. То је управо добар историјски пример који би могао да укаже на улогу коју су епски садржаји и митолошке нелеидске историјске и псеудоисторијске везе имале приликом избора личних имена у градовима малоазијске Јоније. Извесно је да се мудрац из Пријене звао Бијант,

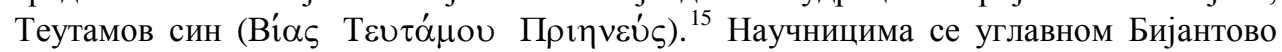
име није учинило посебно интересантним, већ, пре свега, име његовог оца Теутама

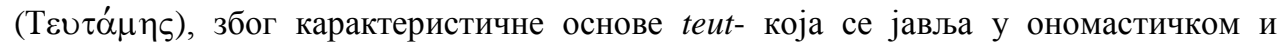
антропонимијском материјалу различитих народа у старини и у различитим индоевропским језицима (на пример, у личним именима типа Teuta, Teuticus, Teutios, Teutates, такође као етник Teutoni, упор. модерно deutsch). Код Хелена су, међутим, ово и сродна образовања такође могла имати херојски призвук. ${ }^{16}$ Традиција такође зна да су грађани Пријене Бијанту одавали херојске почасти и

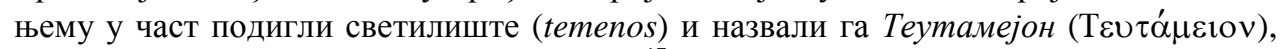
управо према имену његовог оца Теутама. ${ }^{17}$

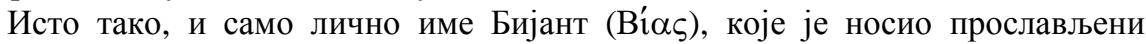
Пријењанин, име је које је могло бити преузето из херојског репертоара грчких имена. Иако је наизглед реч о сасвим обичном образовању, где је антропоним Bí

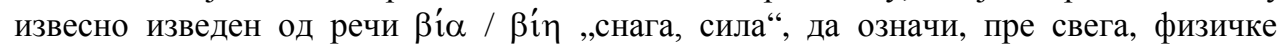

\footnotetext{
${ }^{14}$ I. Priene 37 (арбитража Рођана); I. Priene 41 (арбитража Римљана).

${ }^{15}$ Упор. Diog. Laert. I 82.

16 За Теутама, Бијантовог оца, као и за друга имена са основом teut- која се срећу још код Хомера, а присутна су и у грчкој антропонимији историјских епоха, упор. M. Obradović, TEYTIOY EIMI. A Bronze Situla from Graešnica (Upper Macedonia), Živa antika LII, Skopje 2002, 211-218.

${ }^{17}$ Diog. Laert. I 88. Међутим, епиграфски извори који сведоче и постојању Бијантовог култа у Пријени

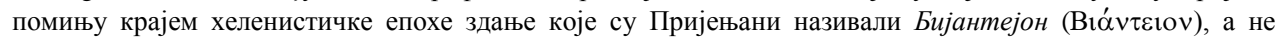
Теутамејон. Вид. I. Priene 111, ред 245, 113, ред 88, 117, ред 34. Упор. С. Р. Jones, New Heroes in Antiquity: From Achilles to Antinoos, Cambridge Mass. - London 2010, 46.
} 
карактеристике особе, носиоца имена, ${ }^{18}$ доста тога говори у прилог томе да име није случајно одабрано у једној од најугледнијих пријенских породица. За Бијанта и његову породицу је остало забележено у традицији да су водили порекло из Тебе, односно да је он баш потомак оних Тебанаца који су основали Пријену. ${ }^{19}$ То, наравно, није морало да значи да је Бијант водио директно порекло од оикиста Пријене, већ да се његова породица у својој генеалогији везивала за хероја из беотске Тебе, а што познија традиција, очекивано, није знала правилно да разуме. Бијантова породица у тој ствари није представљала никакав изузетак, већ је, напротив, слична пракса била добро позната и код других аристократских родова у архајском периоду грчке историје. Легендарне тебанске, а нарочито кадмејске везе, имале су значајну улогу у креирању идентитета аристократије у различитим деловима хеленског света, а нарочито у градовима малоазијске Јоније. Оне су могле представљати капитал у друштвеним превирањима и политичкој борби која се распламсавала у оквиру полиса. ${ }^{20} \mathrm{C}$ друге стране, од више митских и епских Бијаната, који су могли послужити као узор код избора личног имена за славног

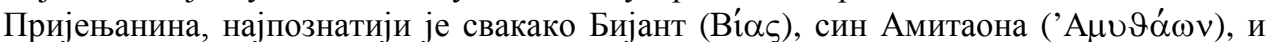
брат славног пророка и лекара хероја Мелампода (Мє $\lambda \alpha \dot{\mu} \mu \pi \nu \varsigma)$, од рода Ајоловог, ${ }^{21}$ један од легендарних краљева Арга на Пелопонезу. Овога Бијанта, као и неке друге Ајолове потомке, међутим, поред Арга и Арголиде, много тога у традицији везује и за Месенију на Пелеопонезу и самог Нелеја, оснивача града Пила. Херој Бијант се на крају и оженио Нелејевом ћерком Перо и са њом имао славно потомство. ${ }^{22}$ Син

\footnotetext{
${ }^{18}$ Упор. Н. von Kamptz, Homerische Personennamen: sprachwissenschaftliche und historische Klassifikation, Göttingen 1982, 233, који рачуна и са могућношћу да лично име Вíaৎ представља скраћени облик имена

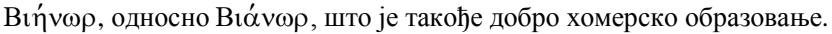

${ }^{19}$ Diog. Laert. I 83. За Филоту, сина Пенелејевог, оикиста Пријене, и занимљиву традицију о оснивању града, упор. М. В. Sakellariou, La migration grecque en Ionie, Athènes 1958, 79-81.

20 Да су поједини писци и сам град Пријену називали Кадмејом (Ко́ $\delta \mu \eta)$, упор. Strab. XIV 1, 12. За мишљење да се и херојско име Кадмо јавља као лично име у аристократским породицама, а нарочито у јонским градовима, да би се истакла њихова веза са светом хероја, упор. M. Obradović, Notes on the Name Kadmos as a Personal Name in the Greek-speaking World, Зборник Филозофског факултета у Београду, Серија А: Историјске науке, књига ХХ, Београд 2006, Sobria ebrietas: У спомен на Мирона Флашара, 191-204.

${ }^{21}$ Упор. генеалогију забележену код логографа Хеланика, FGrHist 4 F 99 = Schol. Euripid. Phoen. 150. Од осталих херојских носилаца овог имена, Бијант је и Атињанин који је у боју под Тројом био сврстан уз свог вођу Менестеја у борби против тројанског принца Хектора (Hom. Il. XIII 691), али такође и један од Пријамових синова (Hom. Il. XX 460, упор. Biantes kod Hyg. Fab. 90). Бијант је, међутим, у Тројанском рату и Пиљанин који се налазио у табору Нестора, краља Пила (Hom. Il. IV 296). Исто се у познијој традицији звао и Лелегов син, један од митских краљева Спарте (Apollod. Bibl. III 15, 5). Није можда онда ни случајно да је име Бијант (Bías) потврђено као лично име и у Спарти у класичном периоду (Plut. Apophth. Lac. 219c). Упор. P. Poralla, A Prosopography of Lacedaemonians from the Earliest Times to the Death of Alexander the Great/Prosopographie der Lakedaimonier bis auf Zeit Alexanders des Großen (Second Edition with an Introduction, Addenda and Corrigenda by Alfred S. Bradford), Chicago 1985, 35. Да је име овог Лакедемоњанина преузето из херојског репертоара личних имена за сигурно узима већ F. Bechtel, Die historischen Personennamen des Griechischen bis zur Keiserzeit, Halle 1917, 572.

${ }^{22}$ Већ у хесиодовском Каталогу жена (Hes. Cat. F 27) се наводи Талај као син из брака Бијанта и Перо, а познија традиција зна за још најмање два сина и једну ћерку као резултат ове везе. Упор. M. L. West, The Hesiodic Catalogue of Women. Its Nature, Structure, and Origins, Oxford 1985, 79 нап. 109; M. Hirschberger,
} 
Бијанта и Перо је краљ Талај, а најпознатији Талајев син, дакле Бијантов унук, је, на пример, велики херој Адраст. Осим тога, још песник Одисеје зна да је Бијант остао у Месенији, док је његов брат Мелампод отишао у Аргос где се оженио и добио део

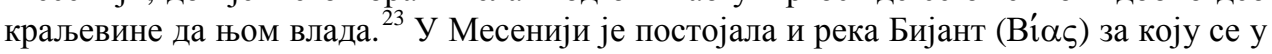
познијој традицији (код периегета Паусаније) наводи да је добила име по хероју Бијанту, Амитаоновом сину. ${ }^{24}$ Вероватније је, међутим, да је било обрнуто, односно да постојање речног тока карактеристичног имена, које указује на снагу и брзину водене струје, стоји у основи каснијег имена хероја. ${ }^{25}$

Постојање реке назива Бијант (Bías) у Месенији, као и ратника Бијанта из Пила у Хомеровој Илијади (Il. IV 296), могло би да укаже да је лично име Бијант (Bías) могло бити доживљавано код Хелена и као месенско, али, пре свега, и као нелеидско име. Можда је у случају имена мудрог Пријењанина могло да се управо ради о још једној потврди постојања нелеидске традиције у Јонији која је настала доста рано и изгледа сасвим независно од Атине и „атинских“ Нелеида. О постојању једне такве нелеидске традиције у Јонији располажемо потврдама у историјским изворима. Неке од њих су у хронолошком погледу веома блиске времену у коме је живео Бијант из Пријене (крај VII, односно прва половина VI века). Добро је познато да велики лирски песник Мимнермо из јонског Колофона у знаменитом фрагменту из своје поеме Нана наводи да су преци Колофоњана у Јонију стигли директно из Нелејевог Пила. ${ }^{26}$ Слична „независна“ нелеидска традиција могла је постојати и у јонској Пријени, напоредо са оном која је изводила порекло грађана, односно бар једног дела заједнице из беотске Тебе. Ради се, као што смо већ навели, заправо о аристократији која је зарад сопствених интереса настојала да се повеже са светом хероја, а преко њих и са боговима. Поред тога, и самог мудраца Бијанта Пријењанина традиција повезује са Месенијом на један необичан и занимљив начин: наводи се да су код њега боравиле заробљене месенске девојке, које је он ослободио и одгајио као своје кћери, обезбедио им мираз и, на крају, вратио их њиховим очевима у Месенију. ${ }^{27}$ За настанак ове приче, која је вероватно лишена сваке веродостојности, и за везу Пријењанина са Месенијом вероватно није без значаја и то да је лично име Бијант савременицима и потоњим генерацијама могло да звучи „месенски“ и нелеидски и да изазива „месенске“ асоцијације. Исто тако, и појава имена Бијант (Bías) као личног имена на острву Хиосу тумачи се понегде у науци могућношћу да је део колониста водио порекло из Месеније. ${ }^{28}$

Gynaikon Katalogos und Megalai Ehoiai. Ein Kommentar zu den Fragmenten zweiter hesiodeischer Epen, München - Leipzig 2004, 250.

${ }^{23}$ Hom. Od. XV 235-41.

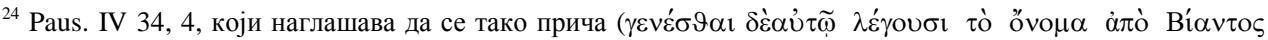

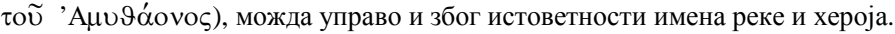

${ }^{25}$ Упор. М. В. Sakellariou, Ethne grecs à l'âge du bronze (MELETHMATA 47), Athènes 2009, 157: „Puisque le sens de $\beta i ́ \alpha$, 'force, puissance' concorde avec la force de l'eau en mouvement, il est loisible de supposer que

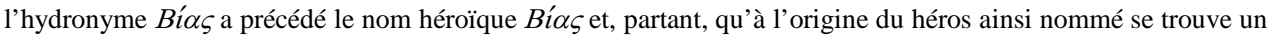
démon fluvial“.

${ }^{26}$ Mimnermus F 9 (ed. M. L. West, Iambi et elegi Graeci II, Oxford $1992^{2}$ ) = Strab. XIV 1, 4.

${ }^{27}$ Упор. Diog. Laert. I 82.

${ }^{28}$ Упор. М. В. Sakellariou, La migration grecque en Ionie, Athènes 1958, 204. 


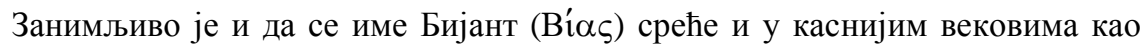
лично име у Пријени. Извесном Бијанту су грађани Пријене у 3. веку пре н.е. одали почасти јер је ваљано и у интересу грађана обављао службу фрурарха (заповедника тврђаве) у Пријени, ${ }^{29}$ а име се јавља у хеленистичком периоду и као име градских магистрата на новцу, ${ }^{30}$ и вероватно сада стоји управо у вези са популарношћу коју је у свом граду уживао Бијант, најславнији грађанин и државник кога је дала малена Пријена. У нешто измењеним историјским околностима лично име Бијант, које је, како смо показали, херојско по своме пореклу, сада је давано не више са погледом на хероја Бијанта већ на конкретну историјску личност, Бијанта, Теутамовог сина, једног од седморице хеленских мудраца архајске епохе ( $\tau \widetilde{\omega} \nu \dot{\varepsilon} \pi \tau \dot{\alpha} \sigma o \varphi \widetilde{\omega} \nu)$. Са овим су се Бијантом грађани Пријене могли идентификовати у наредним вековима и на њега су могли бити посебно поносни, нарочито у хеленистичкој епоси, као и касније у периоду Римског царства.

Извори и литература:

A Lexicon of Greek Personal Names, Volume VA. Coastal Asia Minor: Pontos to Ionia (eds. Th. Corsten, R.W.V. Catling, M. Ricl), Oxford 2010.

Asheri, D., A Commentary on Herodotus Books I-IV, Oxford 2007.

Bechtel, F., Die historischen Personennamen des Griechischen bis zur Keiserzeit, Halle 1917.

Ceccarelli, P., De la Sardaigne à Naxos: le rôle des îles dans les Histoires d'Hérodote, Impressions d'îles (ed. F. Létoublon), Toulouse 1996, 41-55.

Costa, C. D. N., Greek Fictional Letters: a Selection with Introduction, Translation and Commentary, Oxford 2001.

Cusumano, N., Biante e la Sardegna: libertà e felicità in Erodoto, Kokalos Suppl. 15. Erodoto e l'occidente, Palermo 1999, 139-196.

Demand, N., Herodotus and Metoikesis in the Persian Wars, AJPhil 109, Baltimore 1988, 416-423.

Hiller von Gaertringen, F., Inschriften von Priene, Berlin 1906.

Hirschberger, M., Gynaikon Katalogos und Megalai Ehoiai. Ein Kommentar zu den Fragmenten zweiter hesiodeischer Epen, München - Leipzig 2004.

Jones, C. P., New Heroes in Antiquity: From Achilles to Antinoos, Cambridge Mass. - London 2010.

Münsterberg, R., Die Beamtennamen auf den griechischen Münzen, repr. Hildesheim, Zürich - New York 1985.

Obradović, M., TEYTIOY EIMI. A Bronze Situla from Graešnica (Upper Macedonia), Živa Antika LII, Skopje 2002, 211-218.

Obradović, M., Notes on the Name Kadmos as a Personal Name in the Greek-speaking World, Зборник Филозофског факултета у Београду, Серија А: Историјске науке, књига XX, Београд 2006, Sobria ebrietas: У спомен на Мирона Флашара, 191-204.

\footnotetext{
${ }^{29}$ I. Priene 23.

${ }^{30}$ BMC Greek 16, Ionia, London 1892, 229, 232. Упор. R. Münsterberg, Die Beamtennamen auf den griechischen Münzen, repr. Hildesheim, Zürich - New York 1985, 101. Вид. такође A Lexicon of Greek Personal Names, Volume VA. Coastal Asia Minor: Pontos to Ionia (eds. Th. Corsten, R. W. V. Catling, M. Ricl), Oxford 2010, 101, s.v. Bias (7)-(8).
} 
Poralla, P., A Prosopography of Lacedaemonians from the Earliest Times to the Death of Alexander the Great/Prosopographie der Lakedaimonier bis auf Zeit Alexanders des Großen (Second Edition with an Introduction, Addenda and Corrigenda by Alfred S. Bradford), Chicago 1985.

Rosenmeyer, P. A., Ancient Greek Literary Letters: Selections in Translations, New York 2006.

Sakellariou, M. B., La migration grecque en Ionie, Athènes 1958.

Sakellariou, M. B., Ethne grecs à l'âge du bronze (MELETHMATA 47), Athènes 2009.

Kamptz, H. von, Homerische Personennamen: sprachwissenschaftliche und historische Klassifikation, Göttingen 1982.

Wallace, R. W., Charismatic Leaders, A Companion to Archaic Greece (eds. K. A. Raaflaub and H. van Wees), Blackwell Publishing, Oxford 2009, 411-426.

Welles, C. B., Royal Correspondence in the Hellenistic Period, New Haven 1934.

West, M. L., The Hesiodic Catalogue of Women. Its Nature, Structure, and Origins, Oxford 1985. 


\title{
THE WISE MAN BIAS OF PRIENE: THE TRADITION ABOUT HIS TIME, HIS BACKGROUND, AND THE MEANING OF HIS NAME
}

\begin{abstract}
Summary
This paper examines the tradition about Bias of Priene, one of the Seven Wise Men of Greece about whom many stories were told, his background and the meaning of his name. In the absence of reliable historical sources, testimonia mostly come from a variety of disparate sources compiled in Hellenistic times or later and we may only suppose that local anecdotes, proverbs and short sayings reflect historical events. The paper provides detailed treatment of the several conflicting traditions about Bias of Priene. Nevertheless, the surviving biographical information about Bias point to the period of the reign of King Croesus and the Persian conquest of Asia Minor (ca. 560-540 BC), as the best time of his political activity. For this reason he might be designated as the sixthcentury philosopher and statesman who was a generation younger than most others from among the Seven Sages (e.g. Solon of Athens, Thales of Miletus, Pittacus of Mytilene, Periander of Corinth).

In the second part of the paper the possible meaning of the name Bias has been examined. This name as a personal name was almost certainly taken from the heroic repertoire of Greek names with an intention of connecting Bias's family, who obviously belonged to the aristocracy of Priene, with the world of heroes, and through them, with the world of gods. The most famous mythical bearer of the name Bias was the hero Bias, the son of Amythaon and the brother of the legendary seer and healer Melampus. This Bias married Pero, the daughter of Neleus, the founder of Pylos in Messenia, and he had with her glorious offspring, before he settled in Argos. The choice of that heroic name as a personal name in the family of the wise Prienian might not be by chance, and it can be best explained with possible Neleid and Messenian connections generally existing among the local aristocracy in the Ionian poleis of the Archaic period. These connections were quite expected because the Neleids were ubiquitous in foundation myths throughout the Ionian East. Moreover, Messenian associations about Bias of Priene were preserved in the strange story on the Messenian maidens (Diog. Laert. I 82), obviously not well understood by later tradition. This story could allude to an alleged Neleid and Messenian background of the Bias's family. The existence of the Bias River in Messenia also indicates that the personal name Bias could have been perceived by the Greeks as a good Messenian and Neleid name.
\end{abstract}

Keywords: Bias, the Seven Sages, Greek anthroponymy, Archaic period, myth, tradition, history, politics, cultural values. 